Pacific Journal of Mathematic 


\title{
ON ABSOLUTE DE LA VALLÉE POUSSIN SUMMABILITY
}

\author{
B. KWEE
}

Gronwall proved that $(C, r) \cong(V-P)$ for $r \geqq 0$, where $(C, r)$ and $(V-P)$ denote Cesáro and de la Vallée Poussin summability. It is proved in this paper that $|C, r| \leqq|V-P|$ for $r \geqq 0$.

1. Introduction. Let

$$
V_{n}=\sum_{k=1}^{n} \frac{(n !)^{2}}{(n-k) !(n+k) !} a_{k} \quad(n \geqq 0) .
$$

If $\lim _{n \rightarrow \infty} V_{n}=s$, we say that the series is summable $(V-P)$ to $s$. If

$$
\sum_{n=1}^{\infty}\left|V_{n}-V_{n-1}\right|<\infty
$$

The series $\sum_{n=0}^{\infty} a_{n}$ is said to be summable $|V-P|$.

Hyslop [2] proved that the $(V-P)$ method is equivalent to the $(A, 2)$ method defined by

$$
\lim _{x \rightarrow 0+} \sum_{n=0}^{\infty} a_{n} e^{-n^{2} x}=s
$$

for all series $\sum_{n=0}^{\infty} a_{n}$ which satisfy the condition $a_{n}=0\left(n^{c}\right)$, where $c$ is any constant, and that the inclusion $(A, 2) \subseteq(V-P)$ is false without restriction.

Kuttner [3] has shown that $(V-P) \subseteq(A, 2)$ without restriction.

Gronwall [1] proved that $(C, r) \subseteq(V-P)$ for $r \geqq 0$, where $(C, r)$ denotes the Césaro summability of order $r$.

In this paper, we shall prove

Theorem A. $|C, r| \subseteq|V-P|$ for $r \geqq 0$.

2. Proof of Theorem A. Since it is well-known that $|C, r|$ implies $\left|C, r^{\prime}\right|$ for $-1<r \leqq r^{\prime}$, it is enough to consider the case $r$ an integer. Now, writing

$$
V_{n}=v_{0}+v_{1}+\cdots+v_{n}
$$

we find that

$$
\left\{\begin{array}{l}
v_{0}=a_{0}, \\
v_{n}=\sum_{k=1}^{n} \frac{((n-1) !)^{2}}{(n-k) !(n+k) !} k^{2} a_{k} \quad(n \geqq 1) .
\end{array}\right.
$$


Now write $\tau_{k}=\tau_{k}^{r}$ for the $(C, r)$ mean of the sequence $\left\{k a_{k}\right\}$; thus the assumption that $\sum_{n=0}^{\infty} a_{n}$ is summable $|C, r|$ is equivalent to

$$
\sum_{n=0}^{\infty} \frac{\left|\tau_{n}\right|}{n}<\infty
$$

If we take $((n-1) !)^{2} /(n-k !)(n+k)$ ! as meaning 0 whenever $k>n$, we deduce from (1) by $n$ partial summations that, for $n \geqq 1$,

$$
v_{n}=\sum_{k=1}^{n} \Delta_{k}^{r}\left\{\frac{((n-1) !)^{2} k}{(n-k) !(n+k) !}\right\}\left(\begin{array}{c}
k+r \\
k
\end{array}\right) \tau_{k} .
$$

Now it is well-known that in order that the series-to-series transformation

$$
b_{n}=\sum_{k=0}^{\infty} \alpha_{n k} a_{k}
$$

should be that $\sum_{n=0}^{\infty}\left|b_{n}\right|$ converges whenever $\sum_{n=0}^{\infty}\left|a_{k}\right|$ does so, it is necessary and sufficient that

$$
\sum_{n=0}^{\infty}\left|\alpha_{n k}\right|
$$

should be bounded. Thus it is enough to show that, for $k \geqq 1$,

$$
\sum_{n=k}^{\infty}\left|\Delta_{k}^{r}\left\{\frac{((n-k) !)^{2} k}{(n-k) !(n+k) !}\right\}\right|=O\left(k^{-r-1}\right) \text {. }
$$

It is easily seen by induction on $r$ that

$$
\Delta_{k}^{r}\left\{\frac{((n-1) !)^{2} k}{(n-k) !(n+k) !}\right\}=\frac{A^{r}(n, k)((n-1) !)^{2}}{(n-k) !(n+k+r) !},
$$

where $A^{r}(n, k)$ is defined inductively by

$$
\left\{\begin{array}{l}
A^{0}(n, k)=k \\
A^{r+1}(n, k)=(n+k+r+1) A^{r}(n, k)-(n-k) A^{r}(n, k+1) .
\end{array}\right.
$$

Write $P_{j}(k)$ for a polynomial in $k$ of degree not exceeding $j$, possibly different at each occurrence (thus $P_{0}(k)$ denotes a constant). We deduce from (4) by induction that

$$
\begin{aligned}
A^{2 s}(n, k) & =\sum_{j=0}^{s} P_{2 j+1}(k) n^{s-j}, \\
A^{2 s+1}(n, k) & =\sum_{j=0}^{s+1} P_{2 j}(k) n^{s+1-j} .
\end{aligned}
$$

Hence, uniformly in the ranges stated 


$$
A^{r}(n, k)= \begin{cases}O\left(n^{(r+1) / 2}\right) & \left(1 \leqq k \leqq n^{1 / 2}\right) \\ O\left(K^{r+1}\right) & \left(n^{1 / 2}<k \leqq n\right)\end{cases}
$$

Next, for large $n$ uniformly in $k \leqq n^{2 / 3}$ we have, by Stirling's formula

$$
\frac{(n !)^{2}}{(n-k) !(n+k) !}=O(H(n, k))
$$

where

$$
H(n, k)=\left(1-\frac{k}{n}\right)^{-n+k-1 / 2}\left(1+\frac{k}{n}\right)^{-n-k-1 / 2} .
$$

We have

$$
\log H(n, k)=-\frac{k^{2}}{n}+O\left(\frac{k^{3}}{n^{2}}\right)
$$

Now since we supposing that $k \leqq n^{2 / 3}$ we have

$$
\exp \left\{O\left(\frac{k^{3}}{n^{2}}\right)\right\}=O(1)
$$

so that

$$
\frac{(n !)^{2}}{(n-k) !(n+k) !}=O\left\{\exp \left(-\frac{k^{2}}{n}\right)\right\}
$$

This will not apply if $k>n^{2 / 3}$. Since we cannot then assert (5). However, for fixed $n,(n !)^{2} /(n-k) !(n+k)$ ! is a decreasing function of $k$ so that, for $k>n^{2 / 3}$,

$$
\frac{(n !)^{2}}{(n-k) !(n+k) !}=O\left\{\exp \left(-n^{1 / 3}\right)\right\} \text {. }
$$

Also, it is trivial that

$$
\frac{((n-1) !)^{2}}{(n-k) !(n+k+2) !}=\frac{(n !)^{2}}{(n-k) !(n+k) !} O\left(n^{-r-2}\right) .
$$

Combining these results, we find that

$$
\Delta_{k}^{r}\left\{\frac{((n-1) !)^{2} k}{(n-k) !(n+k) !}\right\}= \begin{cases}O\left(n^{-(r+3) / 2}\right) & \left(1 \leqq k \leqq n^{1 / 2}\right) \\ O\left(\frac{k^{r+1}}{n^{r+2}} \exp \left(-\frac{k^{2}}{n}\right)\right) & \left(n^{1 / 2}<k \leqq n^{2 / 3}\right) \\ O\left(n^{-1} \exp \left(-n^{-(1 / 3)}\right)\right) & \left(n^{2 / 3}<k \leqq n\right)\end{cases}
$$

Thus the sum (3) is 


$$
\begin{aligned}
& O\left\{\sum_{k \leqq n<k / 2} \frac{1}{n} \exp \left(-n^{-(1 / 3)}\right)\right\}+O\left\{\sum_{k^{3 / 2} \leqq n<k^{2}} \frac{k^{r+1}}{n^{r+2}} \exp \left(-\frac{k^{2}}{n}\right)\right\}+O\left\{\sum_{n \geqq k^{2}} \frac{1}{n^{(r+3) / 2}}\right\} \\
& =O\left(I_{1}\right)+O\left(I_{2}\right)+O\left(I_{3}\right)
\end{aligned}
$$

say. It is clear that

$$
\begin{aligned}
& I_{1}=O\left(k^{-r-1}\right), \\
& I_{3}=O\left(k^{-r-1}\right)
\end{aligned}
$$

so we need consider only $I_{2}$. Now for fixed $k$

$$
\frac{k^{r+1}}{y^{r+2}} \exp \left(-\frac{k^{2}}{y}\right)
$$

is increasing for $y<y_{0}$ and decreasing for $y>y_{0}$, where $y_{0}=y_{0}(k)=$ $k^{2} /(r+2)$. Hence

$$
I_{2} \leqq k^{r+1} \int_{k^{3 / 2}-1}^{k^{2}+1} \frac{1}{y^{r+2}} \exp \left(-\frac{k^{2}}{y}\right) d y+\frac{k^{r+1}}{y_{0}^{r+2}} \exp \left(-\frac{k^{2}}{y_{0}}\right)
$$

The second term on the right of (6) is a constant multiple of $k^{-r-3}$. The first does not exceed

$$
k^{r+1} \int_{0}^{\infty} \frac{1}{y^{r+2}} \exp \left(-\frac{k^{2}}{y}\right) d y
$$

Putting $y=k^{2} / w$, this becomes

$$
k^{-r-1} \int_{0}^{\infty} w^{r} e^{-w} d w=\Gamma(r+1) k^{-r-1},
$$

hence the result.

\section{REFERENCES}

1. T. H. Gronwall, Über eine summationsmethode und ihre anwendung auf die Fouriersche reihe, J. Für Math., 147 (1916), 16-25.

2. J. M. Hyslop, Some relations between the de la Vallée Poussin and Abel methods of summability, Proc. London Math. Soc., (2), 40 (1936), 449-467.

3. B. Kuttner, The relation between de la Vallée Poussin and Abel summability, Proc. London Math. Soc., 44 (1938), 92-99.

Received May 28, 1971.

UNIVERSITy OF MaLaya

KUALA LUMPUR

MaLAYSIA 


\section{PACIFIC JOURNAL OF MATHEMATICS}

\section{EDITORS}

\section{H. SAMELSON}

Stanford University

Stanford, California 94305

\section{R. HOBBY}

University of Washington

Seattle, Washington 98105

\section{J. DugundjI}

Department of Mathematics University of Southern California Los Angeles, California 90007

RICHARD ARENS

University of California

Los Angeles, California 90024

\section{ASSOCIATE EDITORS}
E. F. BECKENBACH
B. H. NeumanN
F. WOLF
K. YOSHIDA

\section{SUPPORTING INSTITUTIONS}

\author{
UNIVERSITY OF BRITISH COLUMBIA \\ CALIFORNIA INSTITUTE OF TECHNOLOGY \\ UNIVERSITY OF CALIFORNIA \\ MONTANA STATE UNIVERSITY \\ UNIVERSITY OF NEVADA \\ NEW MEXICO STATE UNIVERSITY \\ OREGON STATE UNIVERSITY \\ UNIVERSITY OF OREGON \\ OSAKA UNIVERSITY
}

\author{
UNIVERSITY OF SOUTHERN CALIFORNIA \\ STANFORD UNIVERSITY \\ UNIVERSITY OF TOKYO \\ UNIVERSITY OF UTAH \\ WASHINGTON STATE UNIVERSITY \\ UNIVERSITY OF WASHINGTON \\ AMERICAN MATHEMATICAL SOCIETY \\ NAVAL WEAPONS CENTER
}

The Supporting Institutions listed above contribute to the cost of publication of this Journal, but they are not owners or publishers and have no responsibility for its content or policies.

Mathematical papers intended for publication in the Pacific Journal of Mathematics should be in typed form or offset-reproduced, (not dittoed), double spaced with large margins. Underline Greek letters in red, German in green, and script in blue. The first paragraph or two must be capable of being used separately as a synopsis of the entire paper. The editorial "we" must not be used in the synopsis, and items of the bibliography should not be cited there unless absolutely necessary, in which case they must be identified by author and Journal, rather than by item number. Manuscripts, in duplicate if possible, may be sent to any one of the four editors. Please classify according to the scheme of Math. Rev. Index to Vol. 39. All other communications to the editors should be addressed to the managing editor, Richard Arens, University of California, Los Angeles, California, 90024.

50 reprints are provided free for each article; additional copies may be obtained at cost in multiples of 50 .

The Pacific Journal of Mathematics is published monthly. Effective with Volume 16 the price per volume (3 numbers) is $\$ 8.00$; single issues, $\$ 3.00$. Special price for current issues to individual faculty members of supporting institutions and to individual members of the American Mathematical Society: $\$ 4.00$ per volume; single issues $\$ 1.50$. Back numbers are available.

Subscriptions, orders for back numbers, and changes of address should be sent to Pacific Journal of Mathematics, 103 Highland Boulevard, Berkeley, California, 94708.

PUBLISHED BY PACIFIC JOURNAL OF MATHEMATICS, A NON-PROFIT CORPORATION

Printed at Kokusai Bunken Insatsusha (International Academic Printing Co., Ltd.), 270, 3-chome Totsuka-cho, Shinjuku-ku, Tokyo 160, Japan. 


\section{Pacific Journal of Mathematics}

\section{Vol. 42, No. $3 \quad$ March, 1972}

Catherine Bandle, Extensions of an inequality by Pólya and Schiffer for vibrating membranes ................................ 543

S. J. Bernau, Topologies on structure spaces of lattice groups.......... 557

Woodrow Wilson Bledsoe and Charles Edward Wilks, On Borel product measures .......................................

Eggert Briem and Murali Rao, Normpreserving extensions in subspaces of

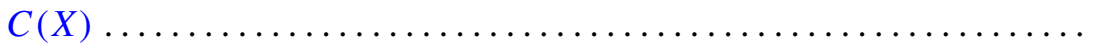

Alan Seymour Cover, Generalized continuation.................. 589

Larry Jean Cummings, Transformations of symmetric tensors .......... 603

Peter Michael Curran, Cohomology of finitely presented groups .......... 615

James B. Derr and N. P. Mukherjee, Generalized quasicenter and

hyperquasicenter of a finite group ...................... 621

Erik Maurice Ellentuck, Universal cosimple isols .................. 629

Benny Dan Evans, Boundary respecting maps of 3-mainfolds .......... 639

David F. Fraser, A probabilistic method for the rate of convergence to the

Dirichlet problem .................................. 657

Raymond Taylor Hoobler, Cohomology in the finite topology and Brauer

groups ..................................... 667

Louis Roberts Hunt, Locally holomorphic sets and the Levi form ........ 681

B. T. Y. Kwee, On absolute de la Vallée Poussin summability............ 689

Gérard Lallement, On nilpotency and residual finiteness in semigroups .... 693

George Edward Lang, Evaluation subgroups of factor spaces........... 701

Andy R. Magid, A separably closed ring with nonzero torsion pic ....... 711

Billy E. Rhoades, Commutants of some Hausdorff matrices ............. 715

Maxwell Alexander Rosenlicht, Canonical forms for local derivations . . . . 721

Cedric Felix Schubert, On a conjecture of L. B. Page ................ 733

Reinhard Schultz, Composition constructions on diffeomorphisms of $S^{p} \times S^{q}$

J. P. Singhal and H. M. (Hari Mohan) Srivastava, A class of bilateral generating functions for certain classical polynomials ....

Richard Alan Slocum, Using brick partitionings to establish conditions which insure that a Peano continuum is a 2-cell, a 2-sphere or an annulus...

James F. Smith, The p-classes of an $H^{*}$-algebra ...

Jack Williamson, Meromorphic functions with negative zeros and positive

poles and a theorem of Teichmuller ................. 